\title{
A TEST OF GRAHAM'S AND LYNCH'S STOCK SCREENING CRITERIA ON SHARES TRADED ON THE INDONESIAN STOCK EXCHANGE (IDX)
}

\author{
Dwi Kartikasari \\ Politeknik Negeri Batam \\ (dwi@polibatam.ac.id)
}

\begin{abstract}
Benjamin Graham and Peter Lynch listed criteria for screening stocks, which investors could use to identify undervalued stocks that would outperform the market. Numerous tests have been conducted in the United States and other countries, but not yet in Indonesia. Thus, the author aims to test the applicability of Graham's and Lynch's formulation on shares traded on the Indonesian Stock Exchange (IDX) by screening stocks that meet the various sets of Graham's and Lynch's criteria and then measuring the performance of the portfolios over the years from 2010 to 2014. The author uses a simple linear regression to measure the performance of the portfolios against the IDX Composite (IHSG). The author discovered that investors who used the combined criteria of Lynch earned positive risk-adjusted returns, of 28.81 percent per year in 2010-2012 and 27.33 percent per year in 20122014. While investors who used a combination of two of Graham's criteria obtained significant riskadjusted returns of 47.55 percent annually in 2010-2012 and 5.92 percent annually in 2012-2014. However, investors who implemented a combination of three of Graham's criteria did not earn positive risk-adjusted returns consistently during the research period. The increasingly complex criteria do not improve the performance of the portfolios, because when more criteria are used, less and less stocks can meet the criteria, hence the portfolios become more volatile and investors do not enjoy the benefits from diversification.
\end{abstract}

Keywords: Graham; Lynch; stocks; the Indonesia Stock Exchange (IDX)

JEL Classification: G11, G17

\section{INTRODUCTION}

Adherents of the efficient market hypothesis argue that an investor will not outperform the market constantly, because stock prices reflect all the relevant information, hence stock prices are always at a reasonable price. An investor cannot consistently buy stocks very cheaply and sell them at a profit. To prove this, Malkiel (2007) suggested that most investors never won continuously over the long term. He claimed that no one (or nothing) knows the future, including the past data.

However, Graham (2009) and Lynch (1989) rejected this argument and stated that there are opportunities when the securities market is not fully efficient, hence investors may gain higher returns on a number of stocks that meet their criteria. Graham and Lynch have experience of the chances offered by market inefficiencies. Benjamin Graham is known as the father of value investing. His student, Warren Buffett, became one of the richest people in the world by implementing Graham's principles. Whilst Peter Lynch, during his tenure as the manager of the Magellan Fund, doubled the S\&P market index consistently between 1977 and 1990 and made the fund the best performing mutual fund in the world. Later, Lynch was named the greatest mutual fund manager of all-time.

After revealing their secrets in books, Graham and Lynch are now called the most influential "gurus" in the United States, especially in the field of fundamental analysis. Although more complex than technical analysis, fundamental analysis is very advantageous because it can be used not only to buy stocks, but also to buy private or public companies. The gurus believe that the fundamental analysis based criteria for screening stocks can help 
investors identify undervalued stocks or "baggers" that would outperform the market.

Many tests have been conducted to test the accuracy of Graham's criteria in the United States (Oppenheimer, 1984) and other countries, such as South Africa (Klerck \&Maritz, 1997) and India (Singh \& Kaur, 2014). In the meantime, Lynch's criteria have not been widely tested other than in the United States (Thorp, 2015). However, the author has not found any evidence of either Lynch's or Graham's principles being tested on the Indonesian Stock Exchange (IDX). The author hopes that this article will enrich the literature in this area, especially with the updated data, but also offer confidence to investors, so they continue investing their funds in companies in Indonesia and contribute to Indonesia's economic growth.

\section{Literature Review}

Like Oppenheimer (1984: 69), the author used Graham's criteria as described in Table 1 below.

The above criteria are not used simultaneously because very rarely (if ever) do stocks meet all the criteria (Klerck\& Maritz, 1997; Singh\&Kaur, 2014). In the Burkenroad Reports, if a stock has fulfilled half of the list of Graham's criteria, then the stock analysts buy the stock (Kartikasari, 2013).
Oppenheimer (1984) used only four of the Ben Graham criteria above, namely (1), (3), (6), and (9). He stated that Graham's stocks must meet at least two criteria, consisting of the criteria of "returns" i.e. criteria (1) to (5), and the criteria of "risk" which is criteria (6) to (10). Klerck and Maritz (1997) used three of Graham's criteria, namely (1), (3), and (6). Following Klerck and Maritz (1997), the author also used three criteria, which were Graham's criteria numbers (1), (3), and (6) because of these criteria's simplicity to follow and the availability of the data needed to test these criteria.

Lynch's general criteria as he mentioned in his book "One up on Wall Street" (Lynch, 1989) are:

a) Market capitalization of less than 5 billion dollars. Lynch (1989: 67) argues that big companies have small moves, he favors small cap companies. He does not mention how big a small company is, but almost all investors will agree that it is those whose market capitalization is under US\$2 billion. Because Lynch is less restricted about market cap, this research uses $\$ 5$ billion.

b) The Price/Earnings to Growth ratio (PEG) below 1 .

c) Earnings growth of 15-30 percent. Lynch's favorites are the ones in the 20 to 25 percent range.

Table 1. Benjamin Graham' Stock Selection Criteria

\begin{tabular}{ll}
\hline Number & \multicolumn{1}{c}{ Criteria } \\
\hline$(1)$ & An earnings-to-price yield of at least twice the AAA bond yield. \\
$(2)$ & A Price-Earnings (P/E) ratio of less than 40 percent of the highest price-earnings \\
& ratio the stock had over the past five years. \\
$(3)$ & A dividend yield of at least two-thirds the AAA bond yield. \\
$(4)$ & Stock price below two-thirds of the tangible book value per share. \\
$(5)$ & Stock price below two-thirds of "net current asset value". \\
$(6)$ & Total debt less than the book value. \\
$(7)$ & Current ratio is greater than two. \\
$(8)$ & Total debt less than twice "the current net asset value". \\
$(9)$ & Earnings growth at 7 percent annual (compound) rate, over at least the previous 10 \\
(10) & years. \\
& Stability of the growth of earnings, in that no more than two declines of 5 percent \\
\hline
\end{tabular}

Source: Blustein (1977: 43-45) 
d) A debt ratio of less than 25 percent. Lynch thinks that a normal corporate balance sheet has 25 percent debt out of its total assets.

e) The institutional ownership around 5-65 percent. The lower the better.

This article uses only the criteria of (a) and (d) because of data availability reasons. Thorp (2015) used a slightly modified Lynch's criteria. For example, for criteria (b) he used a PEG of below 0.5 instead of 1 . The Burkenroad Reports also modified Graham's criteria although it still held to the general formula (Kartikasari, 2013).

Graham (2009) formulated that if a stock's price has doubled, or a stock has been held for two years, then it should be looked over according to his criteria, to see whether it should be sold or kept. Lynch (1989) does not mention in detail when to sell a stock, but he states that when the difference of the dividend yield and the risk free rate are less than 6 percent, an investor should sell the stock and buy bonds. Especially for cyclical stocks like housing, automobiles, and paper, he suggests to buy when the $\mathrm{P} / \mathrm{E}$ is low and sell when the $\mathrm{P} / \mathrm{E}$ is high.In this article, in order to be able to compare the performance of Graham's and Lynch's portfolios, the author assumes that an investor is holding the portfolios for two years.

\section{Research Methods}

The data were taken from the financial statements and historical stock prices of all the companies listed on the Indonesian Stock Exchange (IDX, 2015) access to which was granted by the Indonesian Capital Market Electronic Library (iCaMEL). To improve the quality of the data, the author compared the obtained data with the data of Yahoo!Finance and Phillip's On-line Electronic Mart System (POEMS). If there were differences in the data, the author confirmed them using the financial data published on the website of each company.

The financial statements of the first quarter (Q1), by the end of March 2010 and 2012, as well as the closing price data, were used to calculate the dividend yield, market capitalization, and $\mathrm{P} / \mathrm{E}$ ratio as part of the stock selec- tion process. Market cap calculations included BI's middle rate (BI, 2015a). The adjusted closing price, which takes into account the stock split and dividends from the end of June 2010 until June 2014 was used to calculate the performance of the portfolios. The author considered the three months from March to June as a reasonable time period for the investors to gather their data and decide on the shares to purchase.

The author used the Bank Indonesia (BI) rate at the end of March 2010 and 2012 to replace the AAA bond rate (BI, 2015b). This implementation was in accordance with common practices in the Burkenroad Reports that used the 10-year Treasury Bill (Kartikasari et al., 2012) or RSAlong term gilts rates (Klerck\& Maritz, 1997).The author made a portfolio from a combination of equally weighted stocks that meet Graham's or Lynch's criteria. The returns of the portfolio were calculated using the following formula (Ross et al., 2012):

$$
\begin{aligned}
& \text { Total Portfolio Return } \\
& \qquad=\frac{P_{1}-P_{0}+D}{P_{0}}
\end{aligned}
$$

where $\mathrm{P}_{0}$ was the value of the portfolio at the start of the study period, $\mathrm{P}_{1}$ was the value of the portfolio at the end of the study period, and D was the dividend. All the returns were calculated excluding transaction costs and taxes.

The author used the following formula to calculate the risk-adjusted returns, or the excess returns, or the abnormal returns, using the monthly mean returns for 24 months, using the formula of Jensen (1968):

$$
\alpha_{\mathrm{p}}=\left(\mathrm{R}_{\mathrm{pt}}-\mathrm{R}_{\mathrm{ft}}\right)-\beta_{\mathrm{p}}\left(\mathrm{R}_{\mathrm{mt}}-\mathrm{R}_{\mathrm{ft}}\right)-\mathrm{e}_{\mathrm{pt}}
$$

which is derived from the general formula of Jensen (1968):

$$
\mathrm{R}_{\mathrm{pt}}-\mathrm{R}_{\mathrm{ft}}=\alpha_{\mathrm{p}}+\beta_{\mathrm{p}}\left(\mathrm{R}_{\mathrm{mt}}-\mathrm{R}_{\mathrm{ft}}\right)+\mathrm{e}_{\mathrm{pt}}
$$

where:

$$
\begin{aligned}
\alpha_{\mathrm{p}}= & \text { the monthly abnormal/excess returns } \\
& \text { of the portfolio } \\
\mathrm{R}_{\mathrm{pt}}= & \text { the monthly } \mathrm{t}(\mathrm{t}=1, \ldots, 24) \text { returns } \\
& \text { earned by a portfolio of screened } \\
& \text { stocks }
\end{aligned}
$$


$\mathrm{R}_{\mathrm{ft}}=$ the rate of return on a risk free security (BI rate)

$\beta_{\mathrm{p}}=\operatorname{cov}\left(\mathrm{R}_{\mathrm{pt}}, \mathrm{R}_{\mathrm{mt}}\right) / \sigma^{2}\left(\mathrm{R}_{\mathrm{mt}}\right)$, or the portfolio's risk relative to the market portfolio or a premium for accepting the risk

$\mathrm{R}_{\mathrm{mt}}=$ the rate of returns on the market portfolio;

$\mathrm{e}_{\mathrm{pt}}=\mathrm{a}$ random error

The author uses a simple regression analysis to determine whether $\alpha_{p}$ and $\beta_{p}$ are significant by using a t-test. If any of them are significant, the author concludes that after considering the associated risks, the portfolio returns are significantly different to the market returns.

Additionally, to confirm the performance of the portfolios, the author uses Sharpe's ratio (Sharpe, 1966). This is used because not only has it become an industry standard for calculating risk-adjusted returns, but it also includes a volatility component that is crucial in assessing the performance of a portfolio. Although it can be inaccurate when applied to portfolios that do not have a normal distribution of returns, it is easy and simple to apply the following formula (Sharpe, 1966):

$$
\begin{aligned}
& \text { Sharpe's ratio } \\
& =\frac{R_{p t}-R_{f t}}{S D}
\end{aligned}
$$

where $R_{p t}$ is the annualized monthly returns earned by a portfolio of screened stocks, $\mathrm{R}_{\mathrm{f}}$ is the rate of return on a risk-free security (the BI rate), $\mathrm{SD}$ is the annualized standard deviation of the portfolio.

\section{Results and Discussions}

Out of the 385 stocks, the number of stocks that passed Graham's and Lynch's criteria, in addition to their characteristics, are shown in Table 2 below. Table 2 shows that more than 96 percent or 372 out of the 385 stocks pass Lynch's criteria (a). Only two stocks in 2010 and 13 stocks in 2012 pass all three of Graham's criteria of (1), (3), and (6). The more criteria used, the less stocks meet the criteria.

Those that met the three criteria of Graham are stocks with high earnings-to-price ratios and relatively low debt-to-equity ratios. While those that met both of Lynch's criteria are stocks with relatively high market cap, low earnings-to-price ratios and relatively low debt-to-equity ratios. Further characteristics of the selected stocks are described in the Appendix.

The average stocks purchased in 2010 and sold in the next two years increased by 145 percent while those purchased in 2012 increased by 160 percent. During 2010-2012, the combined criteria (1) and (6) screened the highest average returns among all the criteria. Meanwhile, during 2012-2014, the criterion (6) that screened total debts gave the best average returns. Only criterion (6) gave better average returns and higher portfolio returns than the average stock returns and total portfolio returns consistently from 2010 to 2014. Especially for the portfolio returns, only criterion (1) or criterion (6) gave better portfolio returns than the total portfolio. No combined criteria of Graham provided better portfolio returns than the total portfolio returns did consistently over the duration of the study.

\begin{tabular}{|c|c|c|c|c|c|c|c|c|}
\hline \multirow[b]{2}{*}{ Criteria } & \multicolumn{2}{|c|}{ Number of Stocks } & \multicolumn{2}{|c|}{ Market Cap } & \multicolumn{2}{|c|}{ Earnings to Price Price } & \multicolumn{2}{|c|}{ Debt to Equity } \\
\hline & 2010 & 2012 & 2010 & 2012 & 2010 & 2012 & 2010 & 2012 \\
\hline (1) & 115 & 106 & 989 & 4,580 & $42 \%$ & $34 \%$ & 1.60 & 0.86 \\
\hline (6) & 171 & 186 & 4,729 & 8,918 & $12 \%$ & $12 \%$ & 0.50 & 0.49 \\
\hline (1) and (6) & 47 & 34 & 1,297 & 7,602 & $36 \%$ & $35 \%$ & 0.54 & 0.51 \\
\hline$(1),(3),(6)$ & 2 & 13 & 977 & 4,450 & $41 \%$ & $42 \%$ & 0.31 & 0.48 \\
\hline (a) & 372 & 368 & 2,903 & 4,062 & $13 \%$ & $8 \%$ & 2.27 & 0.92 \\
\hline (d) & 56 & 54 & 4,433 & 4,799 & $12 \%$ & $16 \%$ & 0.17 & 0.19 \\
\hline (a) and (d) & 55 & 53 & 3,560 & 3,608 & $12 \%$ & $16 \%$ & 0.17 & 0.19 \\
\hline Total & 385 & 385 & 18,888 & 38,019 & & & & \\
\hline
\end{tabular}

Table 2. The Characteristics of Selected Stocks 
Note: Market cap is in billion Rupiahs. Source: Data analysis.

Table 3. The Returns of Selected Stocks

\begin{tabular}{|c|c|c|c|c|}
\hline \multirow[b]{2}{*}{ Criteria } & \multicolumn{2}{|c|}{ Average Returns } & \multicolumn{2}{|c|}{ Portfolio Returns } \\
\hline & $2010-2012$ & 2012-2014 & 2010-2012 & 2012-2014 \\
\hline (1) & $191 \%$ & $83 \%$ & $80 \%$ & $84 \%$ \\
\hline (6) & $152 \%$ & $285 \%$ & $74 \%$ & $61 \%$ \\
\hline (1) and (6) & $196 \%$ & $125 \%$ & $153 \%$ & $34 \%$ \\
\hline$(1),(3)$, and (6) & $8 \%$ & $127 \%$ & $11 \%$ & $114 \%$ \\
\hline (a) & $148 \%$ & $167 \%$ & $62 \%$ & $58 \%$ \\
\hline (d) & $91 \%$ & $100 \%$ & $75 \%$ & $80 \%$ \\
\hline (a) and (d) & $92 \%$ & $102 \%$ & $78 \%$ & $82 \%$ \\
\hline Total & $145 \%$ & $160 \%$ & $63 \%$ & $50 \%$ \\
\hline
\end{tabular}

Lynch's criterion (a) gives a better average return than the average return of all the stocks, and does so fairly consistently throughout the study period. This finding is consistent with Lynch's prediction that the shares of small companies that are less noticed by the institutional investors, and tend to provide better returns than large companies. Although the average returns of the small caps are better than the average returns of all the stocks, the portfolio returns of criterion (a) are not constantly higher than the total portfolio returns. The portfolio returns of stocks that met criterion (d) and the combined criteria (a) and (d) show a consistently better performance over the duration of the study.

The above returns cannot be compared directly with the IDX Composite (IHSG) because of differences in the calculations' methods. IHSG's calculations take into account the number of shares outstanding, while this study assumes an equal number of shares in the portfolio. In addition, the average returns above are taken from the average returns of each stock without considering the scale of the stock price's differences. Just for readers' reference, the IHSG at the end of June 2010 was 2,913.68; in 2012 it was 3,955.58; and by June 2014 was $4,878.58$. Thus, the IHSG had gone up by 35.76 percent during 2010 to 2012 and 23.33 percent during 2012 to 2014.

When using the IHSG as a reference, the portfolio returns appear to have higher returns than the IHSG's returns. Using the IHSG as a benchmark is reasonable because Oppenheimer
(1984) also used the Center for Research in Security Prices (CRSP) index which represents nearly all of the shares in the United States, as the IHSG does in Indonesia. Therefore, to measure the performance of the portfolio, the author examines whether the portfolio returns remain significantly positive, taking into account the associated risks. According to Jensen (1968), the performance of a portfolio can be seen from the alpha $(\alpha)$ value, using a regression analysis. If a portfolio has a significant positive $\alpha$, it means it has a positive abnormal return. Before carrying out the regression analysis seeking for $\alpha$ 's value, the author tested the classical assumptions of the data. The results of the classical assumptions test are as follows in Table 4.

Table 4 concludes that the data satisfies normality, heteroscedasticity, and autocorrelation tests. The author does not test for multicollinearity because it is not needed for a simple regression with one independent variable. A linearity test is not performed because Jensen (1968) had stipulated a linear model. Normality is detected when Asymp. Sig. (2-tailed) Kolmogorov-Smirnov $\mathrm{Z}$ in Table 4 is more than 0.05 . Durbin-Watson values of between 1.446 and 2,554 (du $<\mathrm{d}<4-\mathrm{du})$, as well as the Sig. (2tailed) Runs tests greater than 0.05 proves that autocorrelation does not exist and the time-series data is randomly distributed. Finally, the absence of homoscedasticity is confirmed once the Sig Glejser exceeds 0.05 (Ghozali, 2009). As soon as the classical assumptions test was fulfilled, the author ran the regression analysis using 
SPSS Statistics 17.0 and obtained the following results in Table 5.

Table 4. Classical Assumptions Test Results

\begin{tabular}{lccccc}
\hline \multicolumn{1}{c}{ Criteria } & Year & $\begin{array}{c}\text { Asymp. Sig. } \\
\text { Kolmogorov-Smirnov Z }\end{array}$ & $\begin{array}{c}\text { Durbin- } \\
\text { Watson }\end{array}$ & $\begin{array}{c}\text { Asymp. Sig. } \\
\text { Runs Test }\end{array}$ & Sig. Glejser \\
\hline (1) and (6) & $2010-2012$ & 0.888 & 2.180 & 0.387 & 0.761 \\
& $2012-2014$ & 0.492 & 1.684 & 0.835 & 0.539 \\
(1), (3), and (6) & $2010-2012$ & 0.863 & 2.328 & 0.196 & 0.642 \\
& $2012-2014$ & 0.590 & $1.444 *$ & 0.297 & 0.447 \\
(a) and (d) & $2010-2012$ & 0.888 & 2.270 & 0.196 & 0.305 \\
& $2012-2014$ & 0.675 & 1.529 & 0.297 & 0.321 \\
\hline
\end{tabular}

* 1.444 is at $\mathrm{dl}<\mathrm{d}<\mathrm{du}$, hence no decision according to the Durbin-Watson test. However, Runs test proves that the data is randomly distributed.

Note: The author tested stocks that met a combination of criteria, not one criterion individually as stipulated by Oppenheimer (1984). Source: Data analysis.

Table 5. The Monthly Compound Returns and Risk-Adjusted Returns of the Portfolios

\begin{tabular}{ccccccccc}
\hline \multirow{2}{*}{ Criteria } & Year & $\begin{array}{c}\text { Monthly Portfolio } \\
\text { Returns }\end{array}$ & $\begin{array}{c}\text { Monthly Market } \\
\text { Returns }\end{array}$ & $\alpha$ & $\mathrm{t}(\alpha)$ & $\mathrm{B}$ & $\mathrm{t}(\beta)$ & $\mathrm{R}^{2}$ \\
\hline (1) and (6) & $2010-2012$ & $3.95 \%$ & $1.28 \%$ & $3.29 \%$ & $2.983^{*}$ & $28.70 \%$ & 1.361 & 0.078 \\
& $2012-2014$ & $1.22 \%$ & $0.88 \%$ & $0.48 \%$ & 0.763 & $72.33 \%$ & $4.422 *$ & 0.471 \\
(1), (3), and (6) & $2010-2012$ & $0.44 \%$ & $1.28 \%$ & $-0.11 \%$ & -0.093 & $16.54 \%$ & 0.757 & 0.025 \\
& $2012-2014$ & $3.23 \%$ & $0.88 \%$ & $3.01 \%$ & 1.271 & $54.77 \%$ & 0.890 & 0.035 \\
(a) and (d) & $2010-2012$ & $2.74 \%$ & $1.28 \%$ & $2.13 \%$ & $2.971^{*}$ & $14.12 \%$ & 1.031 & 0.046 \\
& $2012-2014$ & $2.52 \%$ & $0.88 \%$ & $2.03 \%$ & $1.865^{*} *$ & $27.46 \%$ & 0.970 & 0.041 \\
\hline
\end{tabular}

* Significant at the 1 percent level; ** Significant at the 10 percent level

Source: Data analysis.

All the returns calculated above were monthly mean compound geometrical returns. As can be seen from Table 3 and Table 5, when compared with the IHSG, the portfolios composed of stocks that met the criteria of Graham and Lynch had higher returns, except for stocks that met three of Graham's criteria in 2010. Note that the portfolio of criteria (1) and (6) provided excess returns which were significantly positive in 2012-2014, and which amounted to 0.48 percent per month or 5.92 percent per year and in 2010-2012 amounted to 3.29 percent per month or 47.55 percent per year. By using a combination of two criteria, the risk-adjusted returns of the portfolios were positive, meaning there were statistically significantly higher returns than the IHSG's returns during the study period.

In accordance with the portfolios composed of stocks meeting two of Graham's criteria, those of Lynch's criteria seemed to offer significantly better risk-adjusted returns than the IHSG's returns as well. The Lynch criteria portfolios were able to deliver significantly positive excess returns of 28.81 percent per year in 2010-2012 and 27.33 percent per year in 2012-2014.

Table 5 shows that the performance volatility of Graham's portfolios are consistent with Oppenheimer's research. He mentioned that the performance of portfolios that met three criteria more often showed negative excess returns than portfolios that met only two criteria. Oppenheimer also revealed that since 1976, when Graham published his criteria, the portfolios performance tended to decline, although the portfolios more often provided positive excess returns than negative values, which were either statistically significant or not.

The author uses Sharpe's ratio, a widely used measure by portfolio managers, to confirm Jensen's performance. If the Sharpe's ratio of a 
portfolio is positive, it means that the performance of a portfolio exceeds the benchmark risk-free investment. The greater the Sharpe's ratio is, the better, because the return of a portfolio is then greater than the risk-free rate and the standard deviation of that portfolio is low. However, the standard deviation is less relevant when the data experiences normality problems. Table 6 below shows the Sharpe's ratio of the portfolios along with a description of the normality status (see Table 6).

Table 6 shows that Lynch's portfolio in 2010 provides the largest Sharpe's ratio, equal to 0.633 with the relevant normally-distributed returns. Likewise, the portfolios of two of
Graham's criteria offer fairly high Sharpe's ratios, 0.627 in 2010 and 0.180 in 2012. Thus, the portfolios composed of two of Graham's criteria and those of Lynch's criteria confirm Jensen's positive and significant risk-adjusted returns by showing positive Sharpe's ratios.

Table 6 also shows the stability of a portfolio by comparing the standard deviation of a portfolio with that of the market. Generally, the standard deviations of the portfolios are greater than that of the IHSG, except for Lynch's portfolio in 2010. The movement of the portfolios, relative to the IHSG over the course of the study, can be seen in the following graphs:

Table 6. The Sharpe's Ratio and Normality Relevance

\begin{tabular}{|c|c|c|c|c|c|c|c|c|c|}
\hline Criteria & Year & $\begin{array}{c}\text { Sharpe's } \\
\text { Ratio }\end{array}$ & $\begin{array}{l}\mathrm{SD}_{\mathrm{pt}} \\
(\%)\end{array}$ & $\begin{array}{l}\mathrm{SD}_{\mathrm{mt}} \\
(\%)\end{array}$ & Status & $\begin{array}{l}\text { Kolmogorov- } \\
\text { Smirnov }\end{array}$ & $\begin{array}{c}\text { Skew- } \\
\text { ness }\end{array}$ & $\begin{array}{l}\text { Kurto- } \\
\text { sis }\end{array}$ & $\begin{array}{l}\text { Shapiro- } \\
\text { Wilk }\end{array}$ \\
\hline \multirow[t]{2}{*}{ (1) and (6) } & $2010-2012$ & 0.627 & 5.43 & 5.28 & $\begin{array}{l}\text { Normally } \\
\text { distributed }\end{array}$ & 0.09 & -0.26 & 0.96 & 0.13 \\
\hline & $2012-2014$ & 0.180 & 4.12 & 3.90 & $\begin{array}{l}\text { Normally } \\
\text { distributed }\end{array}$ & 0.14 & -0.83 & 0.62 & 0.21 \\
\hline \multirow[t]{2}{*}{$\begin{array}{l}\text { (1), (3), } \\
\text { and (6) }\end{array}$} & $2010-2012$ & -0.019 & 5.48 & 5.28 & $\begin{array}{l}\text { Not normally } \\
\text { distributed }\end{array}$ & 0.20 & -0.13 & -0.95 & 0.51 \\
\hline & $2012-2014$ & 0.240 & 11.46 & 3.90 & $\begin{array}{l}\text { Not normally } \\
\text { distributed }\end{array}$ & 0.06 & 0.17 & 0.26 & 0.30 \\
\hline \multirow[t]{2}{*}{ (a) and (d) } & $2010-2012$ & 0.633 & 3.47 & 5.28 & $\begin{array}{l}\text { Normally } \\
\text { distributed }\end{array}$ & 0.00 & 0.22 & 0.35 & 0.03 \\
\hline & $2012-2014$ & 0.385 & 5.29 & 3.90 & $\begin{array}{l}\text { Not normally } \\
\text { distributed }\end{array}$ & 0.01 & 0.31 & 5.14 & 0.00 \\
\hline
\end{tabular}

Note: Normal or non-normal decision obtained once the data satisfied a minimum of three tests of normality, i.e. Asymp. Sig. (2-tailed) Kolmogorov-Smirnov Z above 0.05, Skewness and Kurtosis under 2 (George \& Mallery, 2010), and Sig. Shapiro Wilk more than 0.05. Source: Data analysis.

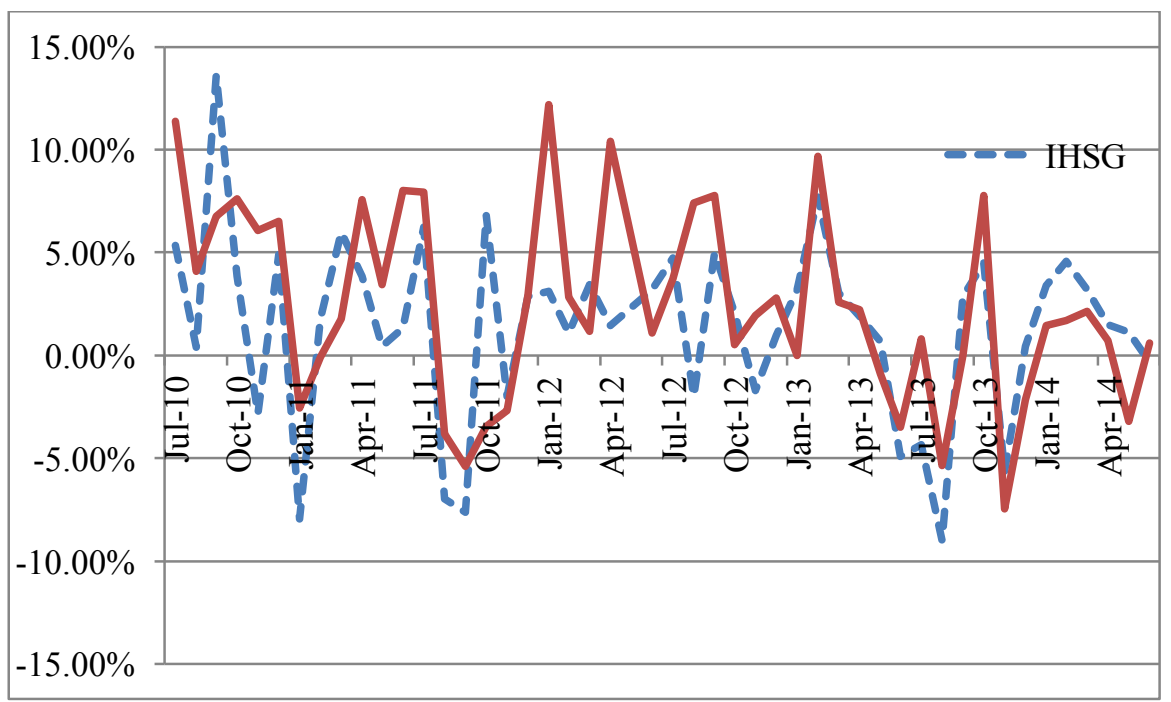


Figure 1. The Portfolio of Graham's Criteria (1) and (6) Vs Index (\% Monthly Returns)

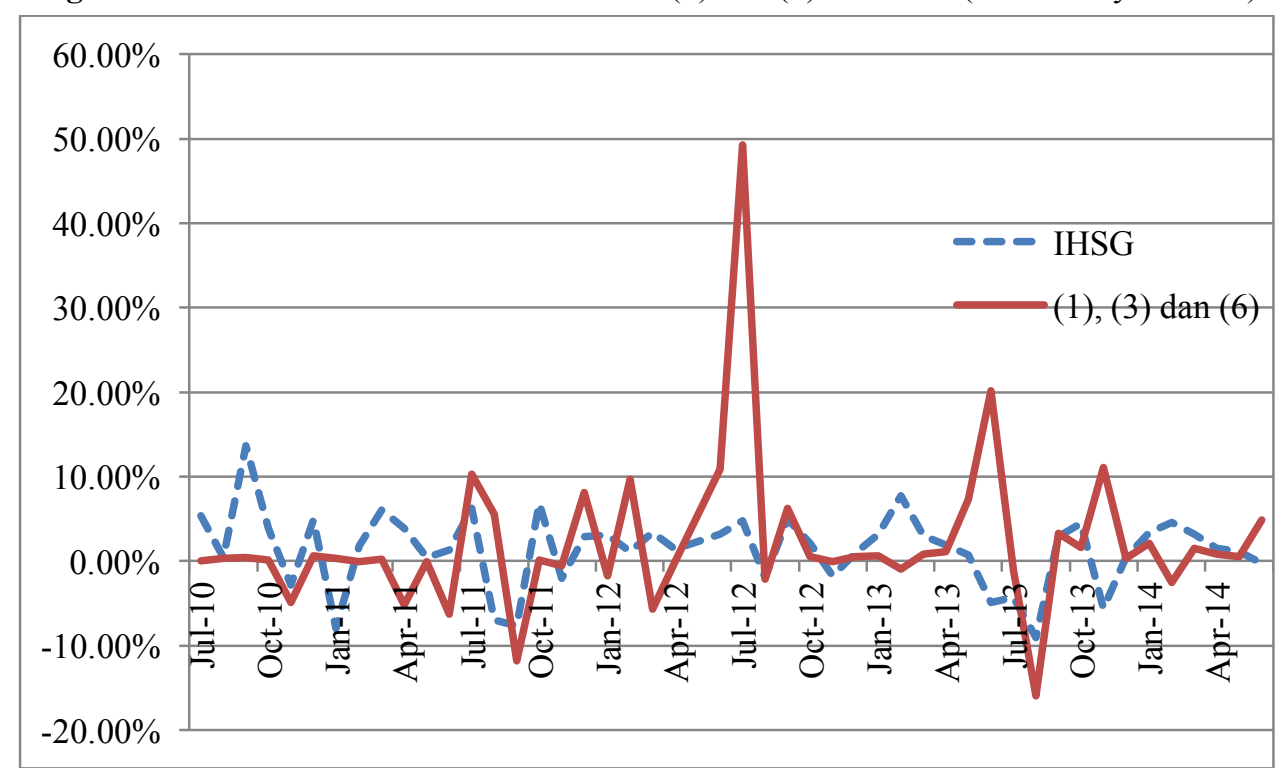

Figure 2. The Portfolio of Graham's Criteria (1), (3) and (6) Vs Index (\% Monthly Returns)

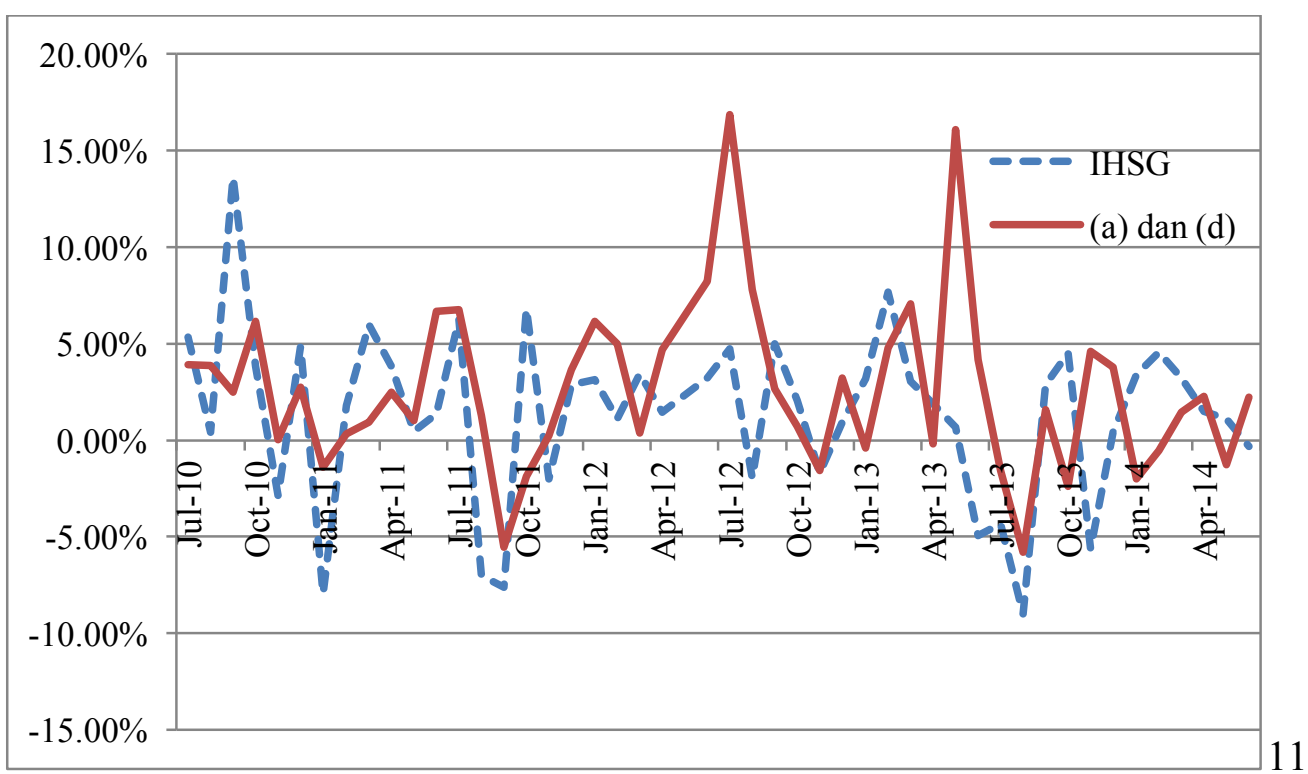

Figure 3. The Portfolio of Lynch's Criteria (a) and (d) Vs Index (\% Monthly Returns)

Figure 1 shows less fluctuation in the returns than the other graphs, when the returns of the portfolios of Graham's two criteria never reach 15 percent. Figure 2 shows that the portfolios of Lynch's criteria tend to offer better returns especially at times when the IHSG falls into negative returns.

Of the three charts above, Figure 2 shows that the portfolio of the three criteria of Graham is more volatile than the portfolios formed by a combination of the other criteria. The high volatility is because of the low number of shares that met the three Graham's criteria requirements, which totalled only two stocks in 2010 and 13 shares in 2012. It seems that the increasingly complex criteria do not better the performance of the portfolios, because when more criteria are used, less and less stocks can 
meet the criteria, hence the portfolio that forms becomes increasingly unstable and investors cannot enjoy the benefits from diversification.

\section{Conclusions and Recommendations}

The author concludes that an investor, who uses the combined criteria of Lynch during the study period, earns positive risk-adjusted returns, which are significantly by 28.81 percent per year in 2010-2012 and 27.33 percent per year in 2012-2014. During the research period, Lynch's portfolios provided high Sharpe's ratios, for instance in 2010-2012 the ratio was equal to 0.633 . By using Lynch's criteria of small caps with debt to assets ratios of less than 25 percent, the author sees the good performance that the portfolios offer, thus the author suggests investors use Lynch's criteria to pick good stocks.

An investor who uses a combination of two of Graham's criteria also obtains significant positive risk-adjusted returns of 47.55 percent annually in 2010-2012 and 5.92 percent annually in 2012-2014. Like Lynch's portfolios, the portfolios formed by stocks that meet two of Graham's criteria also deliver fairly high Sharpe's ratios by 0.627 in 2010-2012 and 0.180 in 2012-2014. Hence, the application of criteria (1) and (6) is strongly recommended.

However, an investor who uses a combination of three of Graham's criteria does not gain any significant and positive risk-adjusted returns. The more increasingly complex criteria do not make the performance of the portfolio better, because when more criteria are used, less and less stocks can meet the criteria, hence the portfolio becomes increasingly volatile and investors cannot enjoy the benefits from diversification. The volatility of the portfolio from three criteria is consistent with Oppenheimer, who showed in his research that the performance of portfolios that met three criteria more often demonstrated negative risk-adjusted returns than portfolios of only two criteria, although in general, Graham's portfolios provide positive riskadjusted returns more frequently than negative ones.

The author hopes that this article can offer confidence to investors in Indonesia's capital market by describing strategies that work, or not, but also enrich the literature in the field of investment. The author understands that she limited the study to only two of Lynch's criteria and only three of Graham's. To that end, in a further study, the author hopes to conduct testing of all the criteria with more diverse combinations of Lynch's and Graham's criteria.

The author notes that like Lynch's and Graham's portfolios, the portfolio of equally weighted stocks of all the shares on the IDX also offers higher returns than those of the IHSG. Therefore for future research, the author suggests a comparative study between these portfolios based on their performance over a longer study period.

Finally, the author recognizes that Lynch's criterion on small caps is actually more suited to conditions in the United States than in Indonesia, because of differences in company scales. To that end, the author hopes that further research can expand the research to observe the effect of modifications to Lynch's (or Graham's) criteria, on the performance of the portfolios.

\section{REFERENCES}

Bank Sentral Republik Indonesia (BI), 2015a. Kalkulator Kurs [Exchange Rate Calculator], BI Website. Available at:www.bi. go.id/id/moneter/kalkulator-kurs/Default. aspx accessed March 27, 2015.

Bank Sentral Republik Indonesia (BI), 2015b. Data BI Rate, BI Website. Available at: www.bi.go.id/id/moneter/bi-rate/data/ Default.aspx accessed March 27, 2015.

Blustein, P., 1977. "Ben Graham's Last Will and Testament", Forbes, August 1, 43 - 45. New Jersey: USA.

George, D., and M. Mallery, 2010. SPSS for Windows Step by Step: A Simple Guide and Reference. $10^{\text {th }}$ ed. Boston: Pearson.

Ghozali, I., 2009. “Analisis Multivariate dengan SPSS" [Multivariate Analysis with SPSS]. Semarang: BPUNDIP.

Graham, B., Rev. Ed, 2009. The Intelligent Investor. USA: Harper Collins.

Indonesia Stock Exchange (IDX), 2015. Unduh Data [Download Data], Bursa Efek Indo- 
nesia Website. Available at: www.idx.co.id/ id-id/beranda/unduhdata/ringkasan.aspx accessed March 27, 2015.

Jensen, M., 1968. "The Performance of Mutual Funds in the Period 1945-1964". The Journal of Finance, May, 389 - 416.

Kartikasari, D., et al., 2012. "Bristow Group Inc (BRS/NYSE) Initiating Coverage: Cruising to New Territory". The Burkenroad Reports, New Orleans, USA: Tulane University.

Kartikasari, D., 2013. "Penerapan Praktis Analisis Fundamental" [Fundamental Analysis Practical Approach]. Jurnal Akuntansi, Ekonomi, dan Manajemen Bisnis, 1(2), 1 5.

Klerck, W.G., and A.C. Maritz, 1997. "A Test of Graham Stock Selection Criteria on Industrial Shares Traded on the JSE". Investment Analysts Journal, 45, 25 - 33.

Lynch, P., 1989. One Up On Wall Street: How to Use What You Already Know To Make Money. USA: Simon and Schuster.
Malkiel, B. G., 2007. A Random Walk Down Wall Street. USA: W. W. Norton \& Company, Inc.

Oppenheimer, H. R., 1984. "A Test of Ben Graham's Stock Selection Criteria". Financial Analysts Journal, 40 (5), 68 - 74.

Ross, S., R.W. Westerfield, and J. Jaffe, $10^{\text {th }}$ ed., 2012. Corporate Finance. USA: McGrawHill Education.

Sharpe, W. F., 1966. "Mutual Fund Performance". Journal of Business, 39 (S1), 119 138.

Singh, J., and K. Kaur, 2014. "Examining the Relevance of Graham's Criteria in Indian Stock Market". Journal of Advances in Management Research, 11 (3), 273 - 289.

Thorp, W.A., 2015. "AAII Stock Screens 2014 Review: Active Strategies Lag". AAII Journal, January 2015, Michigan USA: American Association of Individual Investors. Available at: http://www.aaii.com accessed March 27, 2015. 
APPENDIX

\begin{tabular}{llccccccc}
\hline \multirow{2}{*}{ Year Sector } & \multicolumn{7}{c}{ Criteria } \\
\cline { 2 - 8 } & & $(1)$ & $(6)$ & $(1),(6)$ & $(1),(3),(6)$ & $(\mathrm{a})$ & $(\mathrm{d})$ & $(\mathrm{a}),(\mathrm{d})$ \\
\hline 2010 & Agriculture & 26 & 29 & 13 & 1 & 54 & 9 & 8 \\
& Basic industry \& chemicals & 9 & 20 & 6 & 1 & 27 & 8 & 8 \\
Consumer goods industry & 27 & 16 & 12 & 0 & 63 & 2 & 2 \\
& Finance & 4 & 8 & 2 & 0 & 25 & 1 & 1 \\
Infrastructure, utilities, \& transportation & 4 & 13 & 0 & 0 & 28 & 4 & 4 \\
Mining & 21 & 12 & 5 & 0 & 36 & 2 & 2 \\
Miscellaneous industry & 5 & 26 & 2 & 0 & 43 & 10 & 10 \\
Property, real estate, and building & & & & & & & \\
construction & 18 & 37 & 6 & 0 & 83 & 14 & 14 \\
Trade, services \& investment & 115 & 171 & 47 & 2 & 372 & 56 & 55 \\
\hline Total Number of Companies & 2 & 8 & 1 & 0 & 13 & 4 & 4 \\
\hline 2012 & Agriculture & 15 & 29 & 6 & 2 & 53 & 9 & 8 \\
Basic industry \& chemicals & 7 & 22 & 5 & 1 & 27 & 7 & 7 \\
Consumer goods industry & 29 & 16 & 5 & 3 & 62 & 5 & 5 \\
Finance & 8 & 9 & 1 & 0 & 25 & 0 & 0 \\
Infrastructure, utilities, \& transportation & 7 & 15 & 3 & 1 & 26 & 4 & 4 \\
Mining & 11 & 14 & 5 & 1 & 36 & 4 & 4 \\
Miscellaneous industry & 8 & 29 & 3 & 1 & 43 & 7 & 7 \\
Property, real estate, and building & & & & & & & \\
construction & 19 & 44 & 5 & 4 & 83 & 14 & 14 \\
Trade, services \& investment & 106 & 186 & 34 & 13 & 368 & 54 & 53 \\
\hline Total Number of Companies & & & & & &
\end{tabular}

